\title{
Impact of Workaholics on Creativity: the mediating role of Negative Mood and moderating role of Supervisor Support
}

\author{
Muhammad Abdullah ${ }^{1}$, Naveeda K. Katper ${ }^{2}$,Naveed Iqbal \\ Chaudhry ${ }^{1}$, Muhammad Nawaz Tunio ${ }^{3}$
}

\begin{abstract}
:
Employees are an asset to their organization. The organizations need to provide the best management and supervisory support to their employees to ensure quality work. The current study is based on the workaholic nature of employees and their creative skills. It focuses on the employees of Advertising Agencies. Such organizations need personnel with creative skills and they should develop an environment for their employees to work in a better way and come up with extraordinary results. This study focuses on the impact of workaholics on the creativity of employees the mediating role of negative mood between workaholics and creativity and the moderating role of supervisor support between the workaholics and negative mood. The data has been collected from different advertising agencies of Islamabad and Rawalpindi, through questionnaires with $\mathrm{N}=350$. Results show that workaholics are creative and it has a positive significant relationship with each other. Negative mood plays a mediating role between these two but supervisor support doesn't moderate between workaholics and negative mood. This study helps organizations to increase employee creativity by elevating a negative mood by incorporating several techniques in the context of Pakistani advertising agencies.
\end{abstract}

Keywords: Employee creativity, employee negative mood, supervisor support, workaholics.

JEL Classification: M31

${ }^{1}$ Department of Business Administration, University of the Punjab, Gujranwala ${ }^{2}$ Institute of Business Administration, Faculty of Commerce and Business Administration, University of Sindh, Allama I.I. Qazi Campus Jamshoro

${ }^{3}$ Doctoral Track Entrepreneurship, Innovation and Economic Development, Alpen Adria University, Klagenfurt, Austria

Corresponding Author: m1tunio@edu.aau.at 
Muhammad Abdullah et al. Impact of Workaholics on Creativity: the mediating role of Negative Mood and moderating role of Supervisor Support

\section{Introduction}

In a highly competitive era where every organization is striving for maximum profits and market growth organizational creativity plays a crucial role. Most organizations promote employee creativity to un-tap new dimensions. Organizations need to think out of the box to grab new opportunities. Organizations that leave behind traditional methods and adopt creative solutions can achieve big (Hornsby et al., 2018, Katper, et al., 2020) These days organizations put much emphasis on employee creativity and invest in employee's intellectual development.

The importance of this research is that it helps managers to motivate their employees. Managers may understand how important is it to give a positive environment to the employees in order to bring the best out of them. A theoretical perspective is that it urges researchers to research in several cultural contexts to understand how the psychology of employees work and how managers should play their positive roles in order to help employees to increase their creativity.

A creative employee can easily generate new ideas and can easily manage organizational resources efficiently. A creative employee is a key to organizational development. Numerous commentators argued that employee creativity is "the ability to perceive differently and to generate and execute new ideas to open new dimensions". Creativity is meant to be novel or original and it should be potentially relevant to the organization (Tarakci et al., 2018, Gilal, et al., 2019). Creativity is a property of thought process that can be acquired and improved through instruction and practice. An individual is trained in any way that makes him beneficial (Dewett and Gruys, 2007; Katper, et al., 2020). The creativity of an employee could be of personal characteristics or due to some organizational push. This study aims to check the impact of a personal characteristic of an employee on creativity that is "Work holism" (Hong et al., 2018; Gilal, et al., 2019) "Workaholics have the compulsion and uncontrollable need to work" described by (Oates, 1968). Workaholics are obsessed with some specific work or in general, they need to do work and remain busy every time.

If someone desires to do something, workaholics are contacted. Workaholics considered good feeling about it along with they also help others to do their work and they also find a path to excel as well as to stand out they do extra work. Workaholics with enthusiastic nature tend to create wonders in their specific industries. In tech industries software development, advertising agencies, or in the theatre industry always work enthusiastically succeeded (Garnham, 2005; Gong et al. 2020). There is a category of workaholics who are unable to manage their work or easily become agitated and stressed. Their negative behavior leads to serious issues in their personal and professional lives. On the other hand, few workaholics know how to manage their work and they set up defined goals to achieve so that they don't get overwhelmed by their nature (Abdolshah et al., 2018, Gilal, et al., 2019; Gilal, et al., 2020). Creativity and Innovation are the prerequisites for the survival of individuals in the world of everchanging dynamics and technology. Innovation needs to be practiced professionally and inspiration is the foundation of novelty. The creativity of a person depends upon several

Sukkur IBA Journal of Management and Business - SIJMB | Vol 7 No. 2 July - December 2020 @ Sukkur IBA University 
Muhammad Abdullah et al. Impact of Workaholics on Creativity: the mediating role of Negative Mood and moderating role of Supervisor Support

factors. One factor that effects are negative mood. When a person is psychologically upset or disturbed he/she might have a lower performance level. A person with a negative mood always performs less than average. Creativity level also decreases due to the low mood as creativity demands the full attention and focus of a person. In advertising agencies to enhance employee mood agencies have deployed great setup and ambiances that may help to make the employee feel better (Burroughs and Glen Mick, 2004; Gilal, et al., 2019).

Negative mood is linked with irritability and problems with concentration. When an employee is exposed to something that makes him/her feel bad or give rise to negative emotions then he/she becomes incapable of concentrating on work. Lack of concentration leads to frustration and wastage of time as individuals take longer to get done with the work then required in the state of bad mood. It also lessens the employee's response time (Kamdar et al., 2004). Creativity is about exploring new dimensions and pushing the limits. These pushing limits are risk-taking so an employee with a low mood cannot take the risk to create out of the box happenings. Creativity is about moving from known to unknown. This shift from known to the unknown can easily be accomplished if an employee has supervisor support. A positive relationship between an employee and a supervisor is necessary to have positive work-related outcomes (Oldham, 2003). Creativity is increased when organizational resources are fully utilized and there is no hindrance in using them to put creative ideas into a physical form. The supervisor's support defines the degree of the employee's performance. If the supervisor is supportive and provides employees with proper equipment and resources and facilitates his best then employees will turn up with the best results (Kane, 1993). In advertising agencies, there is an employee-friendly environment that helps employees to relax when there is a burden of work. Most employees are never willing to take the risk. They always look for supervisor's approval or support (Verburg et al., 2018). These days creativity is greatly comprehended and investigated. Today, it becomes an important part of the success of any organization to remain a competitor in the market. Here some limitations that are faced by the individuals to bring creativity. Like negative emotions or moods that individuals especially workaholics complete their daily routine. But, supervisor support plays a positive role while moderating the influence of negative mood, emotion and thus, helps the workaholics to maintain their creativity. In the present research concentration on the Pakistan advertising sector to identifying the gap of creativity of workaholics can be increased by giving them supervisor support and overcoming the effects of negative moods. Today, advertising companies are considered greater profit getting organization. There is a need for companies to remain their employees active, healthy, and stress-free. The current research contributes to facilitating the Pakistan advertisement sector to deal with situations that could have an emotional impact on the good fortune of its impede and employees their creativity skills.

Sukkur IBA Journal of Management and Business - SIJMB | Vol 7 No. 2 July - December 2020 @ Sukkur IBA University 


\section{Literature Review and Hypotheses Development}

\subsection{Workaholics and Creativity}

Workaholics are more inventive along with productivity. Persons have to work for longer hours to shows better creative outcomes. To show high creative results and achievement, individuals have to be converted into hardworking and persistent. Participation in any campaign is a condition of fruitful results. Creative can never give up. They want to work. This type of person cannot prevent themselves from experiments. (Zhang et al., 2018; Mehmood et al., 2020). Skilled young people who were able to concentrate on their work generate incredible results as compared to those who lack creative and amazing abilities. Creativeness is a thing that can be polished with time and only be can through determination and hard work. Individuals who do endless work which can never be forgotten, they also motivated and feel enjoyment while working they can never lose their interest (Mehmood et al., 2020). Workaholics also put the remaining amount of time in an exertion to go below the confines to full the financial needs of the organization. They can work continuously for any advantage of the company and those people are associated with the organization. All the time they think regarding their work. Still, when they do not present physically at the workplace somehow will bring back mentally and they involve with their work. It's a positive sign for organization this type of people can increase the level of creativity due to the involve in work all the time and think regarding it so as they develop new ideas which cannot be developed by others. (Batey et al., 2010).

Workaholics are those individuals who work hard as required from their job other than they can do a lot of effort to completing their goals that are expected by those people who are more associated with the organization and their work. By doing this, they can only want to increase the benefits of the organization. They feel relaxed when they are in the workplace when they are not physically performing work their mind always involve in work this type of person prefers to work physically instead of thinking regarding it (Shimazu et al., 2012). People who show off their creativity create as much information as possible based on their events. This type of person can do the utmost effort and experiments to get satisfactory outcomes from their works. Individuals need to consistently work hard to bring something creative at work. If people a smaller amount of work can never think something from out of the box other than obsessively this can be done by the habit to work or hard working. (Gong et al., 2019a; 2019b). Persons who want to do something different creative can never follow the conventional work style. They can work day and night to ensure their creative procedure and style work. Individuals put greater effort to ensure more novelty (Chen et al., 2019). Innovative people have targets in their minds and they also follow a track which is set by themself. They take new paths and have a greater wish for achievement. (Thompson, 2018). Not only are they successful, but they are always working hard to get their goals. Less successful people do not consistently work like this type of person. Thus, conservation resources theory tenders a comprehensive framework for the development

Sukkur IBA Journal of Management and Business - SIJMB | Vol 7 No. 2 July - December 2020 @ Sukkur IBA University 
Muhammad Abdullah et al. Impact of Workaholics on Creativity: the mediating role of Negative Mood and moderating role of Supervisor Support

of the knowledge about the emotions and performance of the individuals and maintain their performance across different conditions and situations (Halbesleben, et al., 2014). They keep involve themselves in work all the time so that they can polish their ability and skills they have complete command on work whatever they performing any activity. Their interest and effort in work become because they think regarding their work all the time and begin developing the workaholic's qualities. Workaholics always find themselves working. At this stage, work will become a passion for their, and their interest in their work ensures creative outcomes. No doubt, innovation only possible with hard work. First, there is a need for a creative mindset but also brings in action creativity by taking exercise commitment and risks. (Hu et al., 2018). If the employees are not associated with their work cannot think out of the box (Tunio, 2020). The employee can never think innovatively if they are not putting their full efforts and feel enjoyment from their work. No doubt, high power is an important part to ensure innovation. Innovation in work is not possible if employees are not enjoying their works or dull. Therefore, for new experiments employee always needs interest, energy, and enthusiasm. The organization tries to take action which brings employees towards involvement so that they think creatively (Rosing et al., 2018). The above discussion develops the following hypothesis.

\section{H1: There is a significant positive relationship between workaholic and creativity.}

\subsection{The moderating role of Supervisor Support}

Supervisors are said to be supportive when they do not try controlling their employees rather welcome their choices and feelings (Hardré and Reeve, 2009). The supervisor's support is very crucial for employee motivation. Motivation due to the supervisor's support results in positive outcomes (Deci et al., 2001). It is very natural for any person to be more productive when appreciated. Those employees who are less appreciated lose their interest quickly as compared to the ones who are more frequently appreciated. Workaholics tend to work hard and then getting stressed quickly due to workload (Gagné et al., 2000). When supervisor support is there then one might be able to get rid of his negative emotions in less time or one might never come across negative mood as he is being motivated by the supervisor constantly. The supportive environment helps employees to get rid of negative feelings. Motivation helps the individual to get rid of their anxiety, stress, and assist them to recover early from such feelings (Gong et al., 2020; Zhang et al., 2019). Individuals are found to have a positive attitude when supported by both supervisor and people outside the organization.

They love to stand out and when appreciated they work harder next time to come up with something more exciting (Frese et al., 1999). When supervisors supported their employees, they started feeling extraordinarily enthusiastic and happy. Any person when experimenting hesitates for the first time but when he/she is supported and appreciated for what he/she did, it helps them to get rid of his fear and negativity and he is no longer afraid of experimentation (Dursun, 2015). When a supervisor is

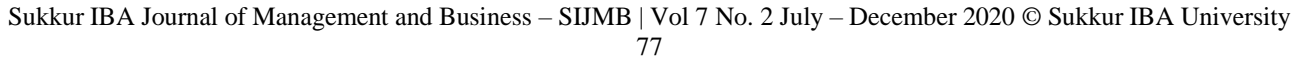


Muhammad Abdullah et al. Impact of Workaholics on Creativity: the mediating role of Negative Mood and moderating role of Supervisor Support

supportive then employees feel satisfied with their job and nothing can make an employee happier then job satisfaction. Any organization which provides its employees with autonomous support and motivation is likely to have more loyal and happy employees.

If employees happen to develop a positive attitude due to support from their supervisors, it can easily be seen in their work. Positive attitude due to supervisor support helps individuals to broaden the relationship between thoughts and actions. Meaning is that individuals will develop an urge to put their ideas into a physical form due to the support from their supervisors (Seo et al., 2004). When the individuals are happy, they feel positive about interacting with others too and this leads to a strong connection building between employees of an organization. Only supervisor support can ensure the development of good relations within an organization. And these relations help employees to be more motivated in what they want to do. It will assist them to think clearly and then to put their thoughts into actions as well (Fredrickson, 2003). Positive affect and charismatic leadership influence motivation and effort. It is very natural that when the supervisor is supportive and listens to employees then they feel comfortable talking to him about every problem that they may cater along the way. They feel free talking to him and sharing their ideas and in response get help from a supervisor. If the supervisor has a compelling personality then they will listen to him that what he has to say about their ideas and they will feel free to take his advice which in turn to be very helpful for employees. The supervisor can help employees with a much better way to reach the goal. And in the end when results also turn out to be positive then this will also strengthen the employee-supervisor relationship (Ilies and Judge, 2005). If an employee tends to develop a negative emotion due to any reason it can immediately be changed into a positive feeling only with a slight motivation from the supervisor side. Supervisor's support helps employees to develop a positive insight about themselves that they can do better and that their effort can lead to a good performance. They start believing in themselves and this helps them endure positive outcomes that are highly creative and innovative (Kanfer and Ackerman, 1989). Positive mood development due to supervisor support also helps employees to be supportive of their coworkers too further developing a strong relationship between employees of the entire organization. And this increases the circle of supportive supervisors and coworkers helping other employees to share their ideas and then collectively putting in the effort to achieve the desired results (Zhang et al., 2019; Gong et al., 2019b). The above literature makes the following hypothesis.

\section{H2: Supervisor support moderates the relationship between Workaholic and negative mood.}

\subsection{Mediating Role of Negative Mood}

This study represents if an employee cannot recover from the work stress this will affect surely their mood (Sonnentag and Bayer, 2005). If the employees cannot recover from

Sukkur IBA Journal of Management and Business - SIJMB | Vol 7 No. 2 July - December 2020 @ Sukkur IBA University 
Muhammad Abdullah et al. Impact of Workaholics on Creativity: the mediating role of Negative Mood and moderating role of Supervisor Support

their stress and frustration then it will negatively affect their mood and which shows from the next day outcomes (G Miner et al., 2005). Negative mood results in a lack of recovery and these mood swings are because of the extra workload that an individual carry. Few individuals for changing the mood in positive terms engaged in leisure events at home, for example, watching TV, talking, online playing games, etc. But some individuals keep their heads in work even at home to get rid of any negative thoughts coming to them which results in less recovery as compared to the former group (Yen et al., 2018). The employees who can't stop thinking regarding their work when coming back home they include in the workaholic's category. They think they must work all the time and stop thinking about work is not possible for them. This type of employee want to work all the time to shows creative and productive results but it can badly be affecting their emotion and moods, weak the strength to recover from this (Siegel et al., 2017). If they suffer long term stress and frustration this will affect their mental state and their focus in work due to this they cannot introduce new creative ideas just because of the pressure of the previous working days' stress (Grob and Bayen, 2017; Tunio, 2020).

Moods are insidious affective conditions that have immense control over employee's behavior and outcomes. Mood describes efficiency. If employees like their work and feel enjoyment while performing shows creative results on the other hand negative mood can affect an employee's creativity. For any person to adopt an environment and for their proper functioning the behaviors must be tuned with their positive feelings and moods (Katz et al., 2018) If an employee does not feel happy or satisfied it is unlikely that he will produce good results. To think creatively they must have a positive mind so they think highly innovative. An employee who is suffering from mental stress cannot think creatively. His thoughts do not let him think creatively and the results are disastrous. Mood provides you with signals that help you to focus on work (De Vos et al., 2017). Negative mood impairs a person's thought process which in turn affects a person's creative skills.

A clean mind can produce artistic miracles but a negative mood can only be ruinous. When an employee is going through a tough time and he feels down then it is more likely that he will not be able to recover soon which also affects his next day routine. He will have cloudy thoughts and would not be able to think straight resulting in less productive work as compared to the previous day. And sometimes it continues to an extent that the individual gives up and is completely out of the competition (Perlman et al., 2017). Peoples have to vary mood at various times so they face varying amendment effects as a concern to the state of mood. If the develop a happy mood then it shows more creative results. Cloudy thoughts only result in dire outcomes.

With the pressure of workload if an employee feels stress cannot work effectively when recovering from this stress properly (Walsh et al., 2018). The employee remains fresh and happy for creative outcomes.

Positive mood endeavors creative results but negative mood only impairs employee creativity. Negative mood lessens workplace creativity. Workaholics tend to work constantly which at times leads to negative emotions and mood swings resulting in less or no recovery for the next day making them unable to produce productive and creative

Sukkur IBA Journal of Management and Business - SIJMB | Vol 7 No. 2 July - December 2020 @ Sukkur IBA University 
Muhammad Abdullah et al. Impact of Workaholics on Creativity: the mediating role of Negative Mood and moderating role of Supervisor Support

results (Watson and Stanton, 2017). Along with the great importance given to emotions and mood by psychologists in recent years, there has been a great deal of interest in the experience and impact of mood on work (Matovic and Forgas, 2018). Employees facing negative consequences in work or the environment they are working in lead to negative mood development that ultimately hinders their creativity and affects the ways they are working (Hsiung and Tsai, 2017). Creativity is measured to be an efficiently indicted event. To produce good results employees' mood satisfaction and happiness plays an important role in creativity. They feel a lot of issues at work if they are not satisfied with their work. The simple example is painter their emotions seen from their painting. It is the same for the employees and workers of any organization. People feel the same way. They surely provide positive and expected results, if the organization gives all supportive environment but if they start experiencing negative emotions then the outcome will be negative too (Ye et al., 2018). The above literature makes the following hypothesis.

\section{H3: Negative mood mediates the relationship between workaholic and creativity}

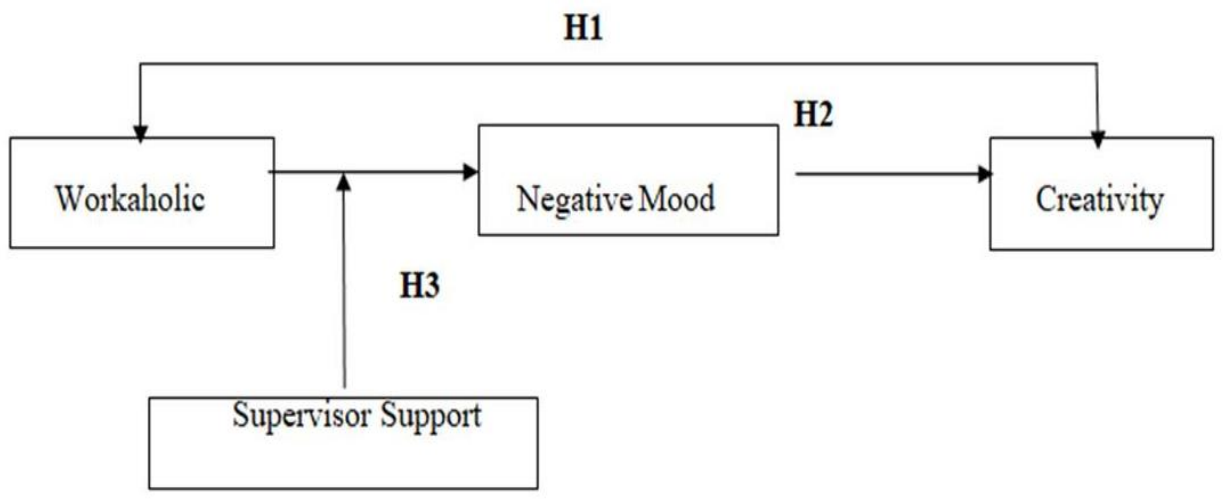

Figure 1: Theoretical framework

\section{Research Methodology}

The residents of Rawalpindi and Islamabad employees of advertising companies are selected for this study. Through the use of questionnaires, data is obtained from various employees of advertising companies located in Rawalpindi and Islamabad. The sample size of this study consists of 350 advertising agency employees. A simple random sampling technique was used for primary data collection. In this sampling technique, respondents have an equal chance of selection from the population. The list of targeted advertising agencies is below.

Sukkur IBA Journal of Management and Business - SIJMB | Vol 7 No. 2 July - December 2020 @ Sukkur IBA University 
Muhammad Abdullah et al. Impact of Workaholics on Creativity: the mediating role of Negative Mood and moderating role of Supervisor Support

Table 1: Advertising Agencies

\begin{tabular}{|l|l|l|}
\hline S. No. & \multicolumn{1}{|c|}{ Names } & \multicolumn{1}{c|}{ No. of respondents } \\
\hline 1. & A.J Advertise Islamabad & 34 \\
\hline 2. & Adsale Advertising & 19 \\
\hline 3. & Time \& Space Media & 34 \\
\hline 4. & Channel 7 Communications & \\
\hline 5. & Black Box Sounds & 37 \\
\hline 6. & Orange Advertising Pvt Ltd. & 59 \\
\hline 7. & MCOM Advertising & 45 \\
\hline 8. & Enhencerz & 4 \\
\hline 9. & Red Communication Arts & 21 \\
\hline 10. & 80M Advertising & 15 \\
\hline 11. & Admagix Advertising \& Marketing & 8 \\
\hline 12. & Creative Sign & 21 \\
\hline 13. & S S Advertising & 9 \\
\hline
\end{tabular}

\section{Instrument}

Data was collected from the respondents through the questionnaire. The questionnaire was used for exact and precise data the questionnaire was adapted according to variables and keeping in mind about literature for research purposes. The questionnaire comprised of the demographic section including 27 items of Workaholic, Negative mood, creativity, and supervisor support.

\section{Measurement}

Based on prior researches (Pathan et al., 2017; Xixiang et al., 2016), we borrowed different scales from existing literature. Robbins and Spence develop a questionnaire in 1992 to study the workaholic this questionnaire was used in this study

(Spence and Robbins, 1992). The total items were 8. Answers were given on a 5-point Likert scale ranging from 1("strongly disagree") to 5("strongly agree"). A questionnaire for negative mood is developed by (Wilson et al., 2005). The total items were 5. Answers were given on a 5-point Likert scale ranging from 1("strongly disagree") to 5("strongly agree"). The questionnaire for creativity is developed by (Mehmood et al., 2019; 2020). The total items were 8. Answers were given on a 5-point Likert scale ranging from 1("strongly disagree") to 5("strongly agree"). A questionnaire for supervisor support is developed by (Jiang and Klein, 1999). The total items were 6. Answers were given on a 5-point Likert scale ranging from 1("strongly disagree") to 5("strongly agree"). Likert-type scale was used as ( $1=$ Strongly Disagree; $2=$ Disagree; $3=$ Neutral; $4=$ Agree; $5=$ Strongly Agree). 
Muhammad Abdullah et al. Impact of Workaholics on Creativity: the mediating role of Negative Mood and moderating role of Supervisor Support

\section{Procedure}

This research selected 13 advertising universities from Islamabad and Rawalpindi. Advertising agency employees were targeted to get responses. Researcher himself went to employees to brief them about the research topic at first and then after their consent collected primary data through questionnaires. Questionnaires were filled on the spot in the presence of the researcher. Targeted advertising agencies were chosen based on ease of the access of employees.

\section{Results and Discussions}

Primary data was entered into SPSS for analyzing results. All data of workaholic, negative mood, creativity, and supervisor support were analyzed through SPSS. For analyzing data multiple tests were applied such as Reliability or Cronbach Alpha test, Pearson Correlation, Regression analysis mediation, and moderation effect tested by using SPSS and Andrew F. Hayes process macros.

Table 2 illustrates the values of Cronbach's Alpha according to (Gial et al., 2018; Hair et al., 1998), if the value of Cronbach's alpha is greater than 0.7 then the instrument will be reliable. The table depicts the values of Cronbach's alpha of workaholic, creativity, negative mood, and supervisor support as $\begin{array}{lllll}0.816 & 0.776 & 0.823 & 0.828\end{array}$ respectively. Hence the instrument is reliable (Morgan et al., 2004).

Table 2: Reliability statistics

\begin{tabular}{|l|l|l|}
\hline Variables & Cronbach's Alpha & No. of Items \\
\hline Workaholics & .816 & 8 \\
\hline Creativity & .776 & 8 \\
\hline Negative Mood & .823 & 5 \\
\hline Supervisor Support & .828 & 6 \\
\hline
\end{tabular}

Table 3: Correlation matrix

\begin{tabular}{|l|l|l|l|l|l|l|}
\hline \multicolumn{2}{|c|}{} & Workaholic & N.Mood & S.S & Creativity & \\
\hline Workaholic & $\begin{array}{l}\text { Pearson } \\
\text { Correlation }\end{array}$ & 1 & & & & \\
\hline N.Mood & $\begin{array}{l}\text { Pearson } \\
\text { Correlation }\end{array}$ & $.379^{* *}$ & 1 & & & \\
\hline S.S & $\begin{array}{l}\text { Pearson } \\
\text { Correlation }\end{array}$ & $.321^{* *}$ & $.258^{* *}$ & 1 & & \\
\hline Creativity & $\begin{array}{l}\text { Pearson } \\
\text { Correlation }\end{array}$ & $.432^{* *}$ & $.397^{* *}$ & $.412^{* *}$ & 1 & \\
\hline
\end{tabular}

** Correlation is significant at the 0.01 level (2-tailed), N.Mood $=$ Negative Mood, S.S $=$ Supervisor Support.

Sukkur IBA Journal of Management and Business - SIJMB | Vol 7 No. 2 July - December 2020 @ Sukkur IBA University 
Muhammad Abdullah et al. Impact of Workaholics on Creativity: the mediating role of Negative Mood and moderating role of Supervisor Support

(pp. 73-92)

Table 3 shows values of correlation between the independent variables (Workaholic, Negative Mood, and Supervisor Support) and dependent variable (Creativity) which are $.432, .197$, and .412 respectively. Considering values of Pearson correlation Workaholic, Negative Mood, and Supervisor Support have moderate relationships with Creativity.

Table 4: Model summary regression

\begin{tabular}{|l|l|l|l|l|l|}
\hline Model & $\mathrm{R}$ & R Square & $\begin{array}{l}\text { Adjusted } \mathrm{R} \\
\text { Square }\end{array}$ & $\begin{array}{l}\text { Std. The error } \\
\text { of } \\
\text { Estimate }\end{array}$ & $\begin{array}{c}\text { Durbin- } \\
\text { Watson }\end{array}$ \\
\hline 1 & $.536^{\mathrm{a}}$ & .287 & .275 & .48439 & 1.884 \\
\hline
\end{tabular}

a. Predictors: (constant) Workaholic, Negative Mood, Supervisor Support.

b. Dependent Variable: Creativity.

The model summary demonstrates the model fit. In the table model summary, the estimation of $\mathrm{R}$ is given which shows the relationship of the variables. The estimation of $\mathrm{R}$ is .536 so it demonstrates the moderate relationship between the creativity and the independent variables. The value of $\mathrm{R}$ square shows how much variance occurs in the dependent variable creativity. $28 \%$ change occurs in the dependent variable creativity due to independent variables and when applied on population the result is $27 \%$ for adjusted $\mathrm{R}$ square. The standard error is $48 \%$ which is due to the other variables.

Table 5: Multiple regression analysis - Model summary (H1)

\begin{tabular}{|c|c|c|c|c|c|c|}
\hline \multirow[t]{2}{*}{ Model } & \multicolumn{2}{|c|}{ Unstandardized } & \multirow{2}{*}{$\begin{array}{l}\text { Standardized t } \\
\text { Beta }\end{array}$} & \multirow[t]{2}{*}{ sig. } & \multirow{2}{*}{$\begin{array}{l}\text { Collinearity } \\
\text { Tolerance }\end{array}$} & \multirow{2}{*}{$\begin{array}{l}\text { Statistics } \\
\text { VIF }\end{array}$} \\
\hline & $B$ & Std.Error & & & & \\
\hline Constant & 1.467 & .281 & & $\begin{array}{l}5.226 \\
.000 \\
\end{array}$ & & \\
\hline Workaholic & .212 & .074 & .224 & $\begin{array}{l}2.842 \\
.005 \\
\end{array}$ & .616 & 1.624 \\
\hline N.Mood & .098 & .068 & .108 & $\begin{array}{l}2.446 \\
.040 \\
\end{array}$ & .690 & 1.450 \\
\hline S.Support & .317 & .074 & .315 & $\begin{array}{l}4.303 \\
.000 \\
\end{array}$ & .714 & 1.400 \\
\hline
\end{tabular}

In the table of coefficient, considering the value of beta from the unstandardized coefficient shows the change in the independent variable will bring change in the dependent variable. If one unit of workaholic increases, there will be a .212 unit increase in creativity, and if the one unit increases in negative mood, there will be .098 units change in creativity. If one unit increases in supervisor support then there will be .317 units change in creativity. In the table of coefficient, the " $t$ " value shows the strength of

Sukkur IBA Journal of Management and Business - SIJMB | Vol 7 No. 2 July - December 2020 @ Sukkur IBA University 
Muhammad Abdullah et al. Impact of Workaholics on Creativity: the mediating role of Negative Mood and moderating role of Supervisor Support

the relationship between the independent and dependent variables. If the value of " $t$ " is more than +2 or -2 . It explains the relationship. Here in this table, $t$ value of workaholic is 2.842 which shows the strong relationship between the workaholic and creativity. Also, the P-value is .005 which is significant as it is less than .05 hence $\mathrm{H} 1$ is accepted. The outcomes show there is a positive association between creativity and workaholics so this hypothesis is accepted. Outcomes show workaholics want to work. Outcomes are supported by the existing literature review. This will show workaholics want to more work with creative skills and productive (Zhou and George, 2003). To produce creative outcomes, it is essential for employees to long hours. Engagement in any activity requires for productive results. Creatives can never give up. They want to work. They can different experiments to get creative outcomes cannot stop themselves from involving in work. It becomes part of their nature to involve in work all the time they feel satisfaction only when their work is appreciated and this will inspire them to more work, they feel happy what they do (Shalley et al., 2000).

The " $t$ " values of negative mood and supervisor support are 2.446 and 4.303 which shows the strong relationship with the creativity and $\mathrm{p}$ values are .040 and .000 respectively which are less than .05 hence step 1 for mediation and moderation is significant.

Table 6: Moderation test

\begin{tabular}{|l|l|l|l|l|l|l|}
\hline & Coeff & Se & \multicolumn{1}{c|}{ T } & P & LLCI & ULCI \\
\hline Constant & 2.8553 & .0567 & 50.3564 & .0000 & 2.7419 & 2.9686 \\
\hline Workaholic & .2161 & .1168 & 1.8510 & .0689 & -.0173 & .4495 \\
\hline $\begin{array}{l}\text { Supervisor } \\
\text { support }\end{array}$ & -.1711 & .0586 & -2.9217 & .0049 &.-2882 & -.0540 \\
\hline Int_1 & .1274 & .0999 & 1.2758 & .2068 & -.0722 & .3271 \\
\hline
\end{tabular}

$\mathrm{Y}=$ Negative Mood

$\mathrm{X}=$ Workaholic

$\mathrm{W}=$ Supervisor Support

To check the impact of the moderating variable that is supervisor support in this research Andrew F. Hayes test is used in the above table. Results showed that for Int_1 the value of $\mathrm{P}$ is .2068 which is greater than .05 so it enlightened that supervisor support does not moderate the relationship between workaholic and negative mood. Hence $\mathrm{H} 2$ is rejected. This means that in this research supervisor's support doesn't have any effect on employees' negative mood even though that employee is workaholic. The mood might have some other factors that can positively impact. The hypothesis that supervisor support moderates the relation between workaholics and negative mood is rejected. Supervisors can help individuals change their behavior but they cannot help them change their mood. The mood can only be changed by reducing the effect of the factor that caused the mood swing. It is an internal feeling that cannot be shaped by supervisor support and completely depends on the factor giving rise to the mood swings (George 
Muhammad Abdullah et al. Impact of Workaholics on Creativity: the mediating role of Negative Mood and moderating role of Supervisor Support

and Zhou, 2007)

Table 7: Mediation test

\begin{tabular}{|l|l|l|l|r|l|l|}
\hline & Coeff & Se & \multicolumn{1}{r|}{ T } & P & LLCI & ULCI \\
\hline Constant & .0000 & .0000 & -.6393 & .5249 & .0000 & .0000 \\
\hline Workaholic & .000 & .0000 & -.0228 & .9819 & .0000 & .0000 \\
\hline $\begin{array}{l}\text { Negative } \\
\text { mood }\end{array}$ & 1.0000 & .0000 & 2.811 & .0000 & 1.0000 & 2.0000 \\
\hline
\end{tabular}

Y= Creativity

$\mathrm{X}=$ Workaholic

$\mathrm{M}=$ Negative Mood

To check the impact of the mediating variable that is a negative mood in this research Andrew F. Hayes test is used in the above table. Results showed for the mediating variable the $\mathrm{P}$-value is .0000 which is significant as it is less than .05 so it enlightened that negative mood mediates the relationship between workaholic and creativity. And the negative mood affects the creativity of an employee. Hence H3 is accepted. This means if an employee has a negative mood then the creativity level of the employee will be disturbed. Even though the employee has a workaholic nature. The following table shows the moderated mediation results of the variables: supervisor support and negative mood. The hypothesis that negative mood mediates the relationship between workaholics and creativity is accepted. This result is also supported by the literature. That when an employee has a negative mood the negative emotions interrupt brain parts differently. These interruptions make one lose focus and the creativity of a person decreases while having a bad mood (George and Zhou, 2002).

To check the impact of moderated mediation Andrew F. Hayes test used and the results showed in the table that LLCI the lower limit confidence interval is -.0896 and the upper limit confidence interval is .3323 which shows that the range is crossing zero limits as the values are in negative for LLCI and ULCI are in positive this means that there is no moderated mediation occurring in this case. This means that for workaholics if they have a negative mood the supervisor support doesn't change their mood and having a negative mood lowers the creativity of workaholics even having supervisor support in the context of Pakistan's advertising agencies. So, for advertising agencies in Pakistan must cater to the employee to get more creative outcomes.

Table 8: Index of moderated mediation

\begin{tabular}{|l|l|l|l|c|}
\hline & Index & BootSe & BootLLCI & BootULCI \\
\hline $\begin{array}{l}\text { Supervisor } \\
\text { Support }\end{array}$ & .1274 & .1063 & -.0896 & .3323 \\
\hline
\end{tabular}

Sukkur IBA Journal of Management and Business - SIJMB | Vol 7 No. 2 July - December 2020 @ Sukkur IBA University 
Muhammad Abdullah et al. Impact of Workaholics on Creativity: the mediating role of Negative Mood and moderating role of Supervisor Support

\section{Implications for Theory and Practices}

This study provides implications for the organizations to develop and improve the support system, mostly in the advertising sector. Keeping consideration, the change in mood and emotions at the workplace for the work, or stressed caused by the work can be productive and creative for the growth of the organization.

\section{Limitations and Future Directions Recommendations, and implications}

In current research data was only collected from those employees who work in Pakistani advertising agencies so these outcomes did not generalize the working condition of the other section organization employees' condition and skills. Cross-sectional data is obtained in the current study. Today's trend is longitudinal studies. However, data was collected through different intervals but due to a shortage of time, longitudinal studies of the variable are not possible. This study has been conducted in the Pakistani context so considering cultural aspects this study is limited in its findings.

Future directions for researchers can be that the present study explored the role moderator between the mediator and the independent variable. It is recommended that the role of a moderator should be studied between the independent and dependent variable. The current study has investigated the role of mediator between workaholics and creativity which shows mediation under the given circumstances. More factors should also be made part of the study to get a clearer picture. The current study model developed only for the investigation of Pakistani advertising agencies. To expand the horizon information, it is recommended to other researchers to study for other industries and organizations. This research is based on a collection of cross-section data. For getting better outcomes and knowledge of this model it can be tested longitudinally.

\section{Conclusion}

It is clear by analyzing primary data results that are collected by questionnaires, workaholic is positively related to creativity and negative mood mediates their relationship. This study highly important for Pakistan advertising agencies employees. Creative people are workaholics or vice versa hence they need a way to deal with the extra workload, work stress, or the negative emotions they come across their routine work. The research defines different ways of coping up with such issues by providing supervisor support and also shows how negative mood mediates the relation between workaholics and creativity and how to get rid of it. More creative employees need in the advertising sector as compared with other industries. Because in this sector, all activities are done creatively, this will only possible through the creative skills of employees without it they can never succeed or remain the competition in the industry. The work or activities going on in the advertising sector are all skill-based and no one can succeed in this field until unless they possess some great creative skills. One might say that the advertising sector consists of workaholics because they constitute employees who are committed to working and they love working. Being a positive thing

Sukkur IBA Journal of Management and Business - SIJMB | Vol 7 No. 2 July - December 2020 @ Sukkur IBA University 
Muhammad Abdullah et al. Impact of Workaholics on Creativity: the mediating role of Negative Mood and moderating role of Supervisor Support

itself, creativity and work holism also constitutes some negative outcomes like the development of negative emotions or mood swings due to extra workload or stress of work for coming up with productive and creative ideas. Hence, if one wants some positive insight and innovative outcomes then they need to make sure that they provide them with the right kind of support that may feel them happy and positive besides a supervisor's support. If proper support is not provided to employees then at one point they might lose their creative skills or their expertise and will not be able to come up with positive and productive outcomes as before and in the end, the organizations will also get affected along with the person himself/herself.

\section{References:}

Abdolshah, M., Mollaaghamirzaei, A. \& Sedady, F. 2018. The relationship between personality traits and workaholism in Iranian public bank employees. International Journal of Applied Behavioral Sciences, 4, 1-7.

Batey, M., Chamorro-Premuzic, T. \& Furnham, A. 2010. Individual differences in ideational behavior: Can the big five and psychometric intelligence predict creativity scores? Creativity Research Journal, 22, 90-97.

Burroughs, J. E. \& Glen Mick, D. 2004. Exploring antecedents and consequences of consumer creativity in a problem-solving context. Journal of consumer research, 31, 402-411.

Chen, C. X., Zhang, J., \& Gilal, F. G. (2019). Composition of motivation profiles at work using latent analysis: theory and evidence. Psychology Research and Behavior Management, 12, 811-824.

De Vos, J., Schwanen, T. \& Witlox, F. 2017. The road to happiness: from mood during leisure trips and activities to satisfaction with life. 96th Annual meeting of the Transportation Research Board (TRB).

Deci, E. L., Ryan, R. M., Gagné, M., Leone, D. R., Usunov, J. \& Kornazheva, B. P. 2001. Need satisfaction, motivation, and well-being in the work organizations of a former eastern bloc country: A cross-cultural study of self-determination. Personality and social psychology bulletin, 27, 930-942.

Dewett, T. \& Gruys, M. L. 2007. Advancing the case for creativity through graduate business education. Thinking Skills and Creativity, 2, 85-95.

Dursun, E. 2015. The relation between organizational trust, organizational support and organizational commitment. African Journal of Business Management, 9, 134156.

Fredrickson, B. 2003. Positive emotions and upward spirals in organizations. In k. Cameron, JE Dutton, \& RE Quinn,(Eds.), Positive organizational scholarship: Foundations of a new discipline. San Francisco: Berrett-Koehler Publishers.

Frese, M., Teng, E. \& Wijnen, C. J. 1999. Helping to improve suggestion systems: Predictors of making suggestions in companies. Journal of Organizational Behavior, 20, 1139-1155.

Sukkur IBA Journal of Management and Business - SIJMB | Vol 7 No. 2 July - December 2020 @ Sukkur IBA University 
Muhammad Abdullah et al. Impact of Workaholics on Creativity: the mediating role of Negative Mood and moderating role of Supervisor Support

(pp. 73-92)

G Miner, A., M Glomb, T. \& Hulin, C. 2005. Experience sampling mood and its correlates at work. Journal of Occupational and Organizational Psychology, 78, 171-193.

Gagné, M., Koestner, R. \& Zuckerman, M. 2000. Facilitating Acceptance of Organizational Change: The Importance of Self-Determination 1. Journal of applied social psychology, 30, 1843-1852.

Garnham, N. 2005. From cultural to creative industries: An analysis of the implications of the "creative industries" approach to arts and media policy making in the United Kingdom. International journal of cultural policy, 11, 15-29.

George, J. M. \& Zhou, J. 2001. When openness to experience and conscientiousness are related to creative behavior: an interactional approach. Journal of applied psychology, 86, 513.

George, J. M. \& Zhou, J. 2002. Understanding when bad moods foster creativity and good ones don't: the role of context and clarity of feelings. Journal of Applied Psychology, 87, 687.

George, J. M. \& Zhou, J. 2007. Dual tuning in a supportive context: Joint contributions of positive mood, negative mood, and supervisory behaviors to employee creativity. Academy of Management Journal, 50, 605-622.

Gilal, N. G., Zhang, J., \& Gilal, F. G. (2018). The four-factor model of product design: scale development and validation. Journal of Product \& Brand Management, 27(6), 684-700.

Gilal, F. G., Channa, N., A., Gilal, N. G., Gilal, R. G. And Shah, S. M. M. (2019) Association between a teacher's work passion and a student's work passion: a moderated mediation model. Psychology Research and Behavior Management 2019:12 889-900.

Gilal, F. G., Zhang, J., Paul, J., \& Gilal, N. G. (2019). The role of self-determination theory in marketing science: An integrative review and agenda for research. European Management Journal, 37(1), 29-44.

Gilal, F. G., Ashraf, Z., Gilal, N. G., Gilal, R. G., Channa, N., A. (2019) Promoting environmental performance through green human resource management practices in higher education institutions: A moderated mediation model. Corporate Social Responsibility and Environment Management 26, 15791590.

Gilal, F. G., Gilal, N. G., Channa, N., A., Gilal, R. G., Gilal, R. G., Tunio, M. N. (2020) Towards an integrated model for the transference of environmental responsibility. Business strategy and the environment 1-10.

Gong, Z., Yang, J., Gilal, F. G., Van Swol, L. M., Yin, K. (2020) Repairing Police Psychological Safety: The Role of Career Adaptability, Feedback Environment, and Goal-Self Concordance Based on the Conservation of Resources Theory. Sage Open 1-11.

Gong, Z., Van Swol, L., Xu, Z., Yin, K., Zhang, N., Gilal, F. G., \& Li, X. (2019a). High-power distance is not always bad: ethical leadership results in feedback Seeking. Frontiers in Psychology, 10, 1-10.

Sukkur IBA Journal of Management and Business - SIJMB | Vol 7 No. 2 July - December 2020 @ Sukkur IBA University 
Muhammad Abdullah et al. Impact of Workaholics on Creativity: the mediating role of Negative Mood and moderating role of Supervisor Support

Gong, Z., Liu, M., Xin, D., Gilal, F. G., Yin, K., \& Zhang, N. (2019b). Coworker feedback-seeking and feedback environment in China: An expectation states theory approach. Social Behavior and Personality: an international journal, 47(9), 1-10.

Grob, J. \& Bayen, U. J. 2017. Effects of dysphoria and induced negative mood on the processes underlying hindsight bias. Cognition and Emotion, 31, 1715-1724.

Halbesleben, J. R., Neveu, J. P., Paustian-Underdahl, S. C., \& Westman, M. (2014). Getting to the "COR" understanding the role of resources in conservation of resources theory. Journal of management, 40(5), 1334-1364.

Hardré, P. L. \& Reeve, J. (2009). Training corporate managers to adopt a more autonomy-supportive motivating style toward employees: An intervention study. International Journal of Training and Development, 13, 165-184.

Hong, J., Hou, B., Zhu, K. \& Marinova, D. 2018. Exploratory innovation, exploitative innovation, and employee creativity: The moderation of collectivism in the Chinese context. Chinese Management Studies, 12, 268-286.

Hornsby, J. S., Messersmith, J., Rutherford, M. \& Simmons, S. 2018. Entrepreneurship everywhere: Across campus, across communities, and Borders. Journal of Small Business Management, 56, 4-10.

Hsiung, H. H. \& Tsai, W. C. 2017. The joint moderating effects of activated negative moods and group voice climate on the relationship between power distance orientation and employee voice behavior. Applied Psychology, 66, 487-514.

Hu, J., Erdogan, B., Jiang, K., Bauer, T. N. \& Liu, S. 2018. Leader humility and team creativity: The role of team information sharing, psychological safety, and power distance. Journal of Applied Psychology, 103, 313.

Ilies, R. \& Judge, T. A. 2005. Goal regulation across time: the effects of feedback and affect. Journal of applied psychology, 90, 453.

Jiang, J. J. \& Klein, G. 1999. Supervisor support and career anchor impact on the career satisfaction of the entry-level information systems professional. Journal of management information systems, 16, 219-240.

Kamdar, B. B., Kaplan, K. A., Kezirian, E. J. \& Dement, W. C. 2004. The impact of extended sleep on daytime alertness, vigilance, and mood. Sleep medicine, 5, 441-448.

Kane, K. F. 1993. Situational factors and performance: an overview. Human Resource Management Review, 3, 83-103.

Kanfer, R. \& Ackerman, P. L. 1989. Motivation and cognitive abilities: An integrative/aptitude-treatment interaction approach to skill acquisition. Journal of applied psychology, 74, 657.

Katper, N. K., Chaudhry, N. I., Tunio, M. N., \& Ali, M. A. (2020). Impact of Leadership Style and Organizational Culture on Organizational Commitment. Sukkur IBA Journal of Management and Business, 7(1), 92-106.

Katper, N. K., Tunio, M. N., Hussain, N., Junejo, A., \& Gilal, F. G. 2020. COVID-19 Crises: Global Economic Shocks vs Pakistan Economic Shocks 5(4), 645-654.

Sukkur IBA Journal of Management and Business - SIJMB | Vol 7 No. 2 July - December 2020 @ Sukkur IBA University 
Muhammad Abdullah et al. Impact of Workaholics on Creativity: the mediating role of Negative Mood and moderating role of Supervisor Support (pp. 73-92)

Katz, E. C., Earnest, D. R. \& Lewis, C. 2018. Impact on Negative Mood and Craving of a Classroom Policy Prohibiting Mobile Technology Use. Journal of Technology in Behavioral Science, 3, 69-76.

Matovic, D. \& Forgas, J. P. 2018. Mood effects on ingratiation: Affective influences on producing and responding to ingratiating messages. Journal of Experimental Social Psychology, 76, 186-197.

Mehmood, M. S., Jian, Z., \& Gilal, F. G. Entrepreneurial leadership and employee innovative behavior: Intervening role of creative self-efficacy. Human Systems Management, 39(3), 367-379.

Mehmood, M. S., Jian, Z., \& Akram, U. (2020). Be so creative they can't ignore you! How can entrepreneurial leaders enhance employee creativity?. Thinking Skills and Creativity, 1-10.

Morgan, G. A., Leech, N. L., Gloeckner, G. W. \& Barrett, K. C. 2004. SPSS for introductory statistics: Use and interpretation, Psychology Press.

Niks, I. M., De Jonge, J., Gevers, J. M. \& Houtman, I. L. 2017. Divergent effects of detachment from work: a day-level study on employee creativity. European Journal of Work and Organizational Psychology, 26, 183-194.

Oates, W. E. 1968. On Being A "Workaholic". Pastoral Psychology, 19, 16-20.

Oldham, G. R. 2003. Stimulating and supporting creativity in organizations. Managing knowledge for sustained competitive advantage, 243-273.

Pathan, Z. H., Jianqiu, Z., Gilal, F. G., \& Salam, S. (2017). Linking ICT utilization to SME's performance: miracle or mirage? The empirical evidence and lesson from Pakistan. International Journal of Information Systems and Change Management, 9(2), 149-166.

Perlman, K. L., Shelby, R. A., Wren, A. A., Kelleher, S. A., Dorfman, C. S., O'connor, E., Kim, C., Johnson, K. S. \& Soo, M. S. 2017. The positive and negative mood following imaging-guided core needle breast biopsy and receipt of biopsy results. Psychology, health \& medicine, 22, 1149-1162.

Rosing, K., Bledlow, R., Frese, M., Baytalskaya, N., Johnson Lascano, J. \& L. Farr, J. 2018. The temporal pattern of creativity and implementation in teams. Journal of Occupational and Organizational Psychology.

Seo, M.-G., Barrett, L. F. \& Bartunek, J. M. 2004. The role of affective experience in work motivation. Academy of Management Review, 29, 423-439.

Shalley, C. E., Gilson, L. L. \& Blum, T. C. 2000. Matching creativity requirements and the work environment: Effects on satisfaction and intentions to leave. Academy of management journal, 43, 215-223.

Shimazu, A., Schaufeli, W. B., Kubota, K. \& Kawakami, N. 2012. Do workaholism and work engagement predict employee well-being and performance in opposite directions? Industrial health, 50, 316-321.

Siegel, E. Y., Haller, M., Cui, R., Trim, R. S., Tate, S. R. \& Norman, S. B. 2017. Examining changes in negative mood regulation expectancies, posttraumatic stress disorder, depression, and substance use following integrated cognitivebehavioral therapy. Substance abuse, 38, 468-472.

Sukkur IBA Journal of Management and Business - SIJMB | Vol 7 No. 2 July - December 2020 @ Sukkur IBA University 
Muhammad Abdullah et al. Impact of Workaholics on Creativity: the mediating role of Negative Mood and moderating role of Supervisor Support

(pp. 73-92)

Sonnentag, S. \& Bayer, U.-V. 2005. Switching off mentally: predictors and consequences of psychological detachment from work during off-job time. Journal of occupational health psychology, 10, 393.

Spence, J. T. \& Robbins, A. S. 1992. Workaholism: Definition, measurement, and preliminary results. Journal of personality assessment, 58, 160-178.

Tarakci, M., Ateş, N. Y., Floyd, S. W., Ahn, Y. \& Wooldridge, B. 2018. Performance feedback and middle managers' divergent strategic behavior: The roles of social comparisons and organizational identification. Strategic Management Journal, 39, 1139-1162.

Thompson, N. A. 2018. Imagination and creativity in organizations. Organization Studies, 39, 229-250.

Tierney, P., Farmer, S. M. \& Graen, G. B. 1999. An examination of leadership and employee creativity: The relevance of traits and relationships. Personnel psychology, 52, 591-620.

Tunio, M. N. (2020). Academic entrepreneurship in developing countries: contextualizing recent debate. In Research Handbook on Entrepreneurship in Emerging Economies. Edward Elgar Publishing.

Verburg, R. M., Nienaber, A.-M., Searle, R. H., Weibel, A., Den Hartog, D. N. \& Rupp, D. E. 2018. The role of organizational control systems in employees' organizational trust and performance outcomes. Group \& organization management, 43, 179-206.

Walsh, L. C., Boehm, J. K. \& Lyubomirsky, S. 2018. Does Happiness Promote Career Success? Revisiting the Evidence. Journal of Career Assessment, 26, 199-219.

Watson, D. \& Stanton, K. 2017. Emotion blends and mixed emotions in the hierarchical structure of affect. Emotion Review, 9, 99-104.

wilson, t. d., centerbar, d. b., kermer, d. a. \& gilbert, d. t. 2005. The pleasures of uncertainty: prolonging positive moods in ways people do not anticipate. Journal of personality and social psychology, 88, 5 .

Xixiang, S., Gilal, R. G., \& Gilal, F. G. (2016). Brand experience as a contemporary source of brand equity in 21 st century: evidence from the Chinese consumer market. Int J Educ Res, 4(9), 63-76.

Ye, Q., Wang, D. \& Li, X. 2018. Promoting employees' learning from errors by inclusive leadership: Do positive mood and gender matter? Baltic Journal of Management, 13, 125-142.

Yen, H.-Y., Chen, P.-H., Ko, Y.-C., Chiang, S.-K., Chang, Y. Y.-C. \& Shiah, Y.-J. 2018. Betel quid chewing, personality and mood: betel quid chewing associated with low extraversion and negative mood. Substance use \& misuse, 1-6.

Zhang, N., Gong, Z. X., Xu, Z., \& Gilal, F. G. (2019). Ethical climate and service behaviours in nurses: The moderating role of employment type. Journal of Advanced Nursing, 75(9), 1868-1876.

Zhang, N., Li, J., Bu, X., Gong, Z., \& Gilal, F. G. (2018). Bridging the Gap between Ethical Climate and Nurses' Service Behaviors: The Critical Role of

Sukkur IBA Journal of Management and Business - SIJMB | Vol 7 No. 2 July - December 2020 @ Sukkur IBA University 
Muhammad Abdullah et al. Impact of Workaholics on Creativity: the mediating role of Negative Mood and moderating role of Supervisor Support

Professional Well-being. International Journal of Mental Health Promotion, 20(3), 99-110.

Zhou, J. \& George, J. M. 2003. Awakening employee creativity: The role of leader emotional intelligence. The leadership quarterly, 14, 545-568. 